\title{
The understanding of nurses who work in mental health regarding compulsory and involuntary hospitalization
}

\author{
Compreensão de enfermeiras atuantes em saúde mental sobre a internação compulsória e involuntária \\ Percepción de las enfermeras actuantes en salud mental sobre la internación compulsiva e involuntaria
}

Mariane da Silva Xavier ${ }^{1}$ Marlene Gomes Terra² Maria Denise Schimith ${ }^{2}$

Marinês Tambara Leite ${ }^{3}$ Maria Henriqueta Luce Kruse ${ }^{1}$ Cristiane Trivisiol Arnemann ${ }^{1}$

1. Universidade Federal do Rio Grande do Sul. Porto Alegre, RS, Brazil.

2. Universidade Federal de Santa Maria. Santa Maria, RS, Brazil.

3. Universidade Federal de Santa Maria.

Campus de Palmeira das Missões, RS, Brazil.
Corresponding author:

Mariane da Silva Xavier.

E-mail: marianesxavier@yahoo.com.br

Submitted on $09 / 06 / 2016$.

Accepted on 02/20/2017.

DOI: 10.1590/2177-9465-EAN-2016-0262

\section{Abstract}

Objective: To analyze the understanding of nurses working in the mental health services regarding compulsory and involuntary hospitalization referred to in the Brazilian Psychiatric Reform Law. Methodology: Qualitative research, with eight nurses from the mental health services. Data collection took place through an open interview, analyzed using Bardin's content analysis. Results: The nurses understand that when psychiatric hospitalization is recommended, the service user must be evaluated in the social and family context. They consider that both forms of hospitalization can cause distress and anxiety to the service user, due to this person finding herself in a place against her will. Conclusion: This study contributes to reflection regarding psychiatric hospitalization as a resource which must be used in specific situations. The success of community-based services is linked to a non-fragmented mental health service for effective implementation of the reorganization of psychiatric care.

Keywords: Commitment of Mentally III; Reform of Health Services; Mental health; Nursing.

\section{Resumo}

Objetivo: Analisar a compreensão de enfermeiras atuantes em serviços de saúde mental sobre internações compulsórias e involuntárias referidas na Lei da Reforma Psiquiátrica Brasileira. Metodologia: Pesquisa qualitativa, com oito enfermeiras de serviços de saúde mental. Coleta de dados através de entrevista aberta, analisados segundo análise de conteúdo de Bardin Resultados: As enfermeiras compreendem que na indicação de internação psiquiátrica o usuário deve ser avaliado no contexto social e familiar. Consideram que ambas as internações podem causar angústia e ansiedade no usuário, devido se encontrar em um lugar contra sua vontade. Conclusão: Este estudo contribui para uma reflexão a respeito das internações psiquiátricas como um recurso que deve ser utilizado em situações especificas. O sucesso dos serviços de base comunitária encontra-se atrelado a uma rede de saúde mental não fragmentada para efetiva implantação da reorganização da assistência psiquiátrica.

Palavras-chave: Internação Compulsória de Doente Mental; Reforma dos Serviços de Saúde; Saúde Mental; Enfermagem.

\section{Resumen}

Objetivo: Analizar la percepción de las enfermeras actuantes en servicios de salud mental sobre las internaciones compulsivas e involuntarias propuestas por la Ley de la Reforma Psiquiátrica Brasileña. Método: Investigación cualitativa realizada con ocho profesionales especializadas en Salud Mental. Datos recolectados mediante entrevista abierta, analizados según el Análisis de Contenido de Bardin. Resultados: Las enfermeras comprenden que en la indicación de internación psiquiátrica el usuario debe ser evaluado en su contexto social y familiar. Creen que las dos internaciones pueden generar angustia y ansiedad, debido estar en un lugar contra su voluntad. Conclusión: Este estudio contribuye a una reflexión sobre las internaciones psiquiátricas como un recurso que debe ser usado en situaciones específicas. El éxito de los servicios basados en la comunidad está vinculado a una red de salud mental que no presenta fragmentación en la aplicación efectiva de la reorganización de la atención psiquiátrica.

Palabras clave: Internación compulsiva de Enfermos Mentales; Reforma de los Servicios de Salud; Salud Mental; Enfermería. 


\section{INTRODUCTION}

Historically speaking, hospitalization was the main form of treatment in mental health. The isolation of people with mental disorders aimed - in the $17^{\text {th }}$ century - to avoid disorder or any type of violation of the social order. ${ }^{1}$ In a doctor-centered space where behavior considered deviant was to be disciplined, the professional nurses had an important role in the organization of the asylums for the insane. ${ }^{2}$ The processes of change in the field of mental health began with the National Anti-Asylum Movement. This movement's demands formed a basis for the creation of Law 10.216/2001, of the Brazilian Psychiatric Reform, which regulates the protection and rights of people with mental disorders. ${ }^{3}$ Besides this, this Law regulates hospitalizations and divides them into three modes: voluntary, which occurs with the service user's consent; involuntary, which occurs without the service user's agreement, and at the request of a third party; and compulsory, which consists of hospitalization ordered by the justice system. It also stipulates that hospitalizations, in any of these modes, may only be indicated when the extra-hospital resources have been shown to be insufficient. ${ }^{3}$ In this context, we understand that the nurse is an important professional, due both to her ability to understand the human being in a comprehensive way and to the communication that she promotes between the health team, the service user and the community, contributing to processes of deconstruction and re-creation of concepts - and the improvement of practices identified with the precepts of the Psychiatric Reform. ${ }^{4}$

In the light of this, we question and reflect on the role of the nurse in the mental health care network, as well as on how the nurse understands compulsory and involuntary hospitalization in the context of the Psychiatric Reform. In spite of the mental health policies and the efforts of the professionals who work in this scenario, we understand that users of the mental health services continue to be stigmatized by society and that the healthcare, in some cases, is presented as fragmented. This fact may be associated with the insufficiency and the unequal distribution of resources, both financial and in terms of human resources, for undertaking mental health actions, with political issues, the training of professionals or even difficulty in decentralizing the services in order to integrate this area of knowledge into primary care. ${ }^{5}$ We consider investment in this issue to be relevant, given the importance of the nurse in the area of mental health. We defend this position on the grounds that it is in the work routine of nurses that reflection takes place regarding professional conduct and public policies in mental health. ${ }^{1}$ Studies have evidenced that difficulties are found in understanding professional practices grounded in the Psychiatric Reform, and that the teaching of nursing continues to be centered around a traditional model, which could be reflected in the work of future nurses. ${ }^{6,7}$ As a result, we consider it important to undertake studies that have repercussions in the qualification of the skills of nurses for responding to the demands of service users and their families, based in their knowledge, constructing their place in the health process, so as to promote greater interaction with other health professionals, consolidating the process of the Psychiatric Reform. ${ }^{8}$
Considering this contextualization, we devised this study with the following research question: What is the understanding of nurses working in the mental health services of a municipality in the interior of the State of Rio Grande do Sul, regarding compulsory and involuntary hospitalization? With a view to answering this question, this investigation's objective consists of analyzing the understanding of the nurses working in mental health services regarding the compulsory and involuntary hospitalization referred to in the Brazilian Psychiatric Reform Law.

\section{METHOD}

Seeking to respond to this study's objective, we selected as our methodological input the qualitative approach of the descriptive exploratory type. This study is the result of a Master's dissertation, and was undertaken in the mental health services of a municipality in the interior of the State of Rio Grande do Sul, which provides attendance through the Unified Health System (SUS). This municipality has the following mental health services offered by the SUS: two general hospitals, one philanthropic, and another which attends purely through the SUS. The philanthropic hospital has a hospitalization unit purely for mental health, constituting of 24 beds, of which, 10 are for male patients aged between 10 and 18 years old, 10 for female patients aged over 18 years old, four beds for female adolescents, and one bed space for a child. The hospital which purely attends the SUS has a hospitalization unit for mental health with 25 mixed beds for adult service users, and a Psychiatric Emergency Center; one Mental Health Outpatient Center, and three Psychosocial Care Centers (CAPS), of which one is a CAPS II, one is a childadolescent CAPS, one a CAPS AD and one a CAPSad for those addicted to alcohol and other drugs.

As a result, the two units in the general hospitals for psychiatric hospitalization constituted the research scenarios the Psychiatric Emergency Center of the General Hospital, which provides attendance purely to the SUS; the CAPS II, the child-adolescent CAPS, and the CAPSad for those addicted to alcohol and other drugs.

The study included nurses working in the area of mental health in services of the SUS, with those who were on leave or holiday in the data collection period being excluded. Upon acceptance, and meeting the criteria established, eight professional nurses participated in the study.

Data collection took place between the months of May and July 2014, through open interviews with each one of the research participants. For this, we used the following question: What is your understanding regarding compulsory and involuntary hospitalization?

The interviews were scheduled ahead of time according to the nurses' availability. After signing the Terms of Free and Informed Consent, the nurses were interviewed in a previously reserved room in the services where the participants worked, with the interviews being recorded using an audio device. The time needed for each interview was not specified. The interviews were terminated when data saturation was reached, at which 
point the objectives were achieved. Later, we transcribed the interviews and - for the process of organizing the data - used the Atlas Ti 7.0 software (Qualitative Research and Solutions), FreeTrial version.

We analyzed the data using content analysis, ${ }^{9}$ which consists of a set of techniques, going through the phases of pre-analysis, exploration of the material and treatment of the results, inference, and interpretation. In the pre-analysis, with the help of the Atlas Ti 7.0 software, we undertook consecutive readings so as to systematize the data. In the first reading, skin reading, we made exhaustive contact with the material so as to emphasize the points of interest. Later, we revised the data emphasized so as to ensure that important points would not be discarded. In the third reading, we codified the data (we organized it by units of meaning so that we would be able to visualize them as groups) in accordance with the research objectives. In the exploration phase, we undertook the categorization, that is, the unadjusted data was treated, emphasizing that which was significant and valid. The organized data was subjected to a process which consisted of localizing groups which met the research objectives. As a result, two categories emerged from the grouping of the units of meanings by similarity. This study will present the category entitled "Compulsory and involuntary hospitalizations: the understandings of nurses who work in the mental health services". In the final phase, of the treatment of the results, inference and interpretation, we undertook the content analysis, proposing inferences and interpretations of the data from the categories, bearing in mind the objectives proposed.

As our theoretical framework, we used the four dimensions or fields that define the process of the Psychiatric Reform as a complex social process, ${ }^{10}$ which are: the epistemological dimension (referent to the production of knowledge and to the construction and deconstruction of concepts); the technical-care dimension (related to construction of the model of care provided in mental health); the juridical-political dimension (which relates to the construction and revision of civil, penal and health legislation, such as Laws, Decrees and Ordinances) and of the sociocultural dimension (which aims to change the relationships between society and the socially-constructed representations regarding madness). The present study focuses on the epistemological dimension. We consider the use of these dimensions important for forming a basis for the research, because they are ways of thinking about the movements, the processes of exchange and transversality in mental health, and establishment of networks between the concepts which permeate this area of work. ${ }^{11}$

The study complied with the ethical requirements present in Resolution N. 466/2012 of the National Health Council; furthermore, the project was approved by the Committee for Ethics in Research involving Human Beings of the Federal University of Santa Maria, on 21 $1^{\text {st }}$ March 2014, under N. 564.014. We began the research after receiving approval from the management of the mental health services and began the interviews after the reading of the terms of consent by the study participants and their signing of two copies. In order to ensure the nurses' anonymity and confidentiality, we chose to use the letter ' $\mathrm{N}$ ' as it is the initial letter of the area in which this study took place, Nursing, followed by a number, indicating the number of participants in the study $\mathrm{N} 1, \mathrm{~N} 2, \ldots . \mathrm{N} 8$.

\section{RESULTS AND DISCUSSION}

Compulsory and involuntary hospitalizations: the understandings of nurses working in the mental health services.

For the nurses who participated in the study, when the person using a the mental health services is received by a health service with a request for hospitalization, it is expected that this person will be evaluated by the team based on the context from which he came, such as the family support network, the sociocultural context and what led to the need for a possible hospitalization.

From the point at which, in a service like the CAPS, we face a situation of this type (hospitalization), it is necessary to recognize the service user's real situation, how this service user is, what his family context is like (N1).

There are patients who arrive here in a deeply disturbed condition, because there were fights at home or in some way there was some sort of frustration. This demonstrates that the family environment, the relationships, and the environment itself where he lives are important, and the person himself has to be more or less balanced (N4).

Mental health is not limited to psychopathology or to semiology, and cannot be reduced to study and treatment which take place in the ambit of the mental illnesses. ${ }^{12}$ The transition from the asylum care model to the psychosocial model of care for the service user leads to recognition of changes related to mental illness, such as: opposition to the concept of the incapacity of the person with a mental disorder, the organization of the services aiming for care in the community, the active participation of the service user in the treatment, and the view of the professionals which is directed towards care for the service user and his or her family. ${ }^{13}$

It is fundamental that the teams from the health services, as well as collaborating with the service user, must help the families in the process of structuring and coexistence with their family member who has a mental disorder. The team's participation, alongside the family members, can be through empowerment referent to the strategies of managing the condition, providing clarification regarding the diagnosis and medications, proposing therapies, among other aspects. When the family feels that it is supported by professionals from the area, it may be able to contribute actively to the process of care for, and social reinsertion of, the service user. ${ }^{14}$

The understanding of the nurses who work in the mental health services in relation to the care reveals that this is not restricted to the service user, but also covers his family. This understanding is associated with the epistemological dimension of the Psychiatric Reform, based on a concept of care which 
perceives the family as a basic resource in the service user's therapy. ${ }^{10}$ The paradigmatic contextualization which emerges in the nurses' accounts points to the act of care regarding the role of the family. In spite of the advances in the area of mental health with the Psychiatric Reform, ratified in 2001, we are living through a transition between the traditional and contemporary. In the traditional paradigm, the family environment was held as being responsible for the loss of reason, the intervention of the discipline of medicine being necessary, which would make it possible to recover or regain the reason of the so-called "madman". It was also considered necessary to separate the "madman" in order to protect his family from his negative influences, such as indiscipline. As a result, the family was designated to wait in its home to receive the so-called "madman" after his recovery ${ }^{15}$ In this paradigm, the hospital was considered to be the place for treatment of the mental alienation, and, for this, there was social isolation and moral treatment.

It is necessary to move beyond this knowledge in which the "madman" was held as incapacitated, kept in closed spaces far from the city centers, without decent treatment and with a focus on the exclusion and segregation of madness. Over the course of the $20^{\text {th }}$ century, the family, little by little, returned to the scene, when it was called upon to participate in the treatment offered to the user of the mental health services; and different understandings regarding the relationship between the family and madness were perceived. The family comes to be seen as support, such that the service user may create bonds, producing other ways of living in society. In the light of this context, the theoretical-practical mechanisms of the traditional paradigm become bankrupt. This requires a review of the concept of knowledge itself as production of truth, or of the neutrality of the sciences, regarding the concept produced by the epistemic framework of psychiatry, such as the concept of alienation/mental illness, therapeutic isolation, degeneration, normality/abnormality and therapy and cure, among others. ${ }^{10}$ The contemporary paradigm criticizes the inefficiency of the asylum and in the care structures. It indicates the need for new concepts in knowing-doing and that these should be reforming in the field of care with a view to new forms of subjectivity and of sociability for the service users and families who need care. In this epistemological process, two concepts are fundamental: deinstitutionalization and disease.

Deinstitutionalization does not mean only de-hospitalization; that is, removing the service users from the hospital institutions without there being therapeutic, social, family, juridical or political support. Separately, deinstitutionalization is an ethical process, of the recognition of practices which do not perceive the service user as an object of the psychiatric knowledge, but which propose to understand the service user in his care based on his concrete life needs. This is a process which encompasses not only the administration of drugs or psychotherapies but which goes beyond this, providing for the service users the construction of concrete possibilities involving sociabilities and subjectivities. ${ }^{16-10}$
The concept of illness, as the principal focus and reason for strategies of normalization and discipline needs to be questionned. The deconstruction of this concept proposes a care for the user of the mental health services which seeks possibilities for coping with the daily difficulties, so that the service user will be able to exercise his rights as a citizen. ${ }^{16-10}$

The nurses who were interviewed understand that, for the families, compulsory or involuntary hospitalization represents a possibility for mitigating their suffering, and constitutes a resource used when other forms of coping have been exhausted, due to the daily risks and severe crises in their residences. This observation is evidenced below:

It is difficult, when some request for involuntary and compulsory hospitalization arrives. We have to work with the family members who urgently need their son or family member to be away from them, whether to reduce the risks which he or she is experiencing, or for the family itself to relax a little and relieve its suffering (N1).

The family members are desperate because of the severe crises at home. As a result, sometimes the outpatient center is overcrowded, the unit is full. Thus, the justice system (compulsory hospitalization) ends up being the last resource for these family members to seek help (N3).

Based on what was presented in the fragments, considering the circumstances which lead the families to request hospitalization, N3 raises one of the situations which lead the family members to request hospitalization via the law courts. These are cases in which there are no spaces for attendance in the outpatient centers, or there are no beds available in the hospitalization units. In these cases, the family members see compulsory hospitalization as a means of guaranteeing care for their family member who is a service user. These times can be a possibility for support and the creation of therapeutic strategies for the service users and their family members. One resource used is elaboration of a Singular Therapeutic Project (PTS), which involves the identification of the needs of the service user and the family, and of the recommendations made by the health team. The PTS outlines an intervention strategy, taking into account the unique characteristics of the service user and his family, rather than placing them within fixed norms which must be complied with. ${ }^{17}$ The hospitalizations, whether they are voluntary, involuntary or compulsory, need to be assessed critically, considering the service user's needs. When they occur, however, they need to be a means for strengthening the care, given that hospitalization units grouped together multi-professional teams, the family, and the service user in crisis. This scenario allows the opportunity for thinking about the crisis and its repercussions in the construction of the therapeutic plan for the person with a mental disorder. Such measures, led by care which seeks the uniqueness and autonomy of the service user and his family members can contribute to the continuity of the monitoring in the extra-hospital services, as well as to the service user's social 
reinsertion. ${ }^{13}$ In the light of this perspective, the family requires professional support, which can help in recovering the family bonds weakened in the process of coping with daily life. This support can be offered not only in the mental health services, but also in the Primary Healthcare Centers (UBS), Family Health Strategy (ESF) centers and even in school environments, through health promotion. ${ }^{18}$

Given that the users of the mental health services may require care for their organic, psychological, psychic or cognitive conditions, the family is recognized as the principal caregiver. ${ }^{19}$ We understand that there is a need for spaces for discussion, geared towards the professionals in the perspective of training in health involved in the construction of a model based in the Psychiatric Reform, in the principles of the SUS and actions of education and health alongside family and caregivers who aim to provide support.

These spaces may be provided through the practices of Continuing Education in Health, as they allow critical reflection on a specified theme, instigating the awakening of attitudes directed towards changes of hegemonic models, such as the asylum and doctor-centered model..$^{20}$ The spaces for Continuing Education in Health focus on ethical-political investment in critical-reflexive training in mental health. Furthermore, the aim for the affirmation of the right to citizenship and breaking with care-based and normalizing policies, which entail the exclusion and stigmatization of the service user. ${ }^{21}$

Continuing Education in Health as a practice which viabilizes spaces for critical-reflexive discussions in relation to the therapy service user and his family can allow problematizations which indicate positive aspects and changes which can be perceived based on the National Anti-Asylum Movement. As a result, based on this, the nurse and her team can assess what needs to be improved in the care for the users of the mental health services, with a view to the service user's right to quality treatment.

According to N6, some changes can be perceived:

I think that the treatments, whether against the patient's will or not, even if they have this need, have changed a lot since the anti-asylum movement, which culminated in Law 10,216. This paradigm which used to be just about hospitals and a few services outside hospital has changed a lot. It took decades for this to change gradually. I think that we are still far short of arriving at the ideal, in relation to the treatment of the patient and to respect for the person (N6).

As N6 indicates, it "used to be just about hospitals and a few services outside hospital". Law 10,216/2001, which focuses on deinstitutionalization, proposes that psychiatric hospitals should not constitute the basis of the care system, and establishes networks of extra-hospital resources. In severe cases, when the extra-hospital resources have been exhausted, hospitalization is necessary and this occurs for short periods, preferentially in general hospitals, emphasizing the consolidation of a model of mental health care which is integrated and community-based. ${ }^{22}$ Based on this, we can perceive that the nurses are supporting/ participating in movements which point to changes in mental health care. This corroborates the deconstruction of some concepts formerly strengthened by the asylum model, such as: isolation, abnormality, normality, mental illness and cure. The deconstructions of these concepts seen as natural in the asylum model lead to questions and reflections which make possible other ways of thinking and other ways of working as nurses. Based on this deconstruction, it is possible to construct other concepts, such as: deinstitutionalization, territory, citizenship, subjectivity, liberty, substitute services, comprehensiveness and family in the construction of a paradigm geared towards the Psychiatric Reform. ${ }^{23}$

Involved in the conceptual changes which bring closer comprehensive, respectful and unique care, the sociocultural dimension of the Psychiatric Reform process proposes that the overcoming of the hegemonic model should not focus only on the changing of the care, which is an element of the technicalcare dimension. According to the sociocultural dimension, it is important that the transformation should be geared towards the place of madness in society's imaginary. ${ }^{10}$ Based on the model proposed under the Psychiatric Reform, it is not enough to transform the care; it is necessary that society should see the user of the mental health services as a person who has the right to quality treatment, and to be integrated into the community, exercising his citizenship.

In this context, involuntary hospitalization is a challenge for the user of mental health services. For N5, in the process of hospitalization, factors such as the emotional and organic psychic state associated with the desire not to be hospitalized, and with lack of knowledge of the service, could create anxiety and distress in the service users. According to N7, the hospitalizations are necessary at some points, and their results can vary according to how each service user experiences this process. This is evidenced in the following excerpts:

The idea would be to hospitalize the person willingly, through voluntary hospitalization. This, however, is rare. They (the service users) see themselves as forced to be in a service where they would rather not be. On the one hand, this is good. But on the other, there is an ambivalence, because the patient is hospitalized without wanting to be, which causes distress and anxiety. The person ends up having to stay in a closed service, with strangers, without accepting the treatment (N5).

It really does depend. We have had hospitalized patients for whom at that point it was what was needed. It was compulsory because the patient couldn't manage. [...] We had a result. The patient became organized after the hospitalization. Sometimes, however, the patient worsens (N7). 
In their accounts, the nurses do not limit themselves to the conceptual differences between compulsory and involuntary hospitalizations. In this account, N7 emphasizes compulsory hospitalization. As it is a legal measure, it cannot be legally questioned, although - from the health perspective - it deserves discussion. From a juridical perspective, based on Law 10,216, compulsory hospitalization does not constitute the simple privation of liberty, but rather, the right of the user of mental health services to treatment, seeking to provide this person with decent treatment, with their subsequent reintegration into their social environment. The above-mentioned measure aims, primarily, for the service user's right to treatment, with a view to protecting himself, his family and third parties. ${ }^{24}$ The psychiatric hospitalizations occasion reflections based in the ambivalence regarding their application. Their aim is to care for and protect the service user from risks to himself and/or to others, and to provide closer contact with other clinics in the general hospitals, and greater availability of therapeutic resources and diagnoses. It can, however, be a time of consternation for the person who experiences it. It is fundamental that the professionals provide support for the service user who is hospitalized and for the family; individually, or even in groups of family members. Providing clarification on the objectives of the hospitalization may represent a qualitative jump in the progression of the service users' mental health and mitigate the distress and anxiety during the process of hospitalization. ${ }^{1}$

In situations in which the patient does not present insight, awareness of his actions, the nurses emphasize that involuntary hospitalization must be considered. When, however, the service user has awareness, and recognizes the reasons for the hospitalization, other possibilities could be considered to be more effective, as N2 and N8 describe:

Involuntary hospitalization is a means that unfortunately has to be done, because in the mental disorder, sometimes, the patient doesn't have insight, and has to be hospitalized (N2).

As a nurse, I think it doesn't work very well. It is not very effective for the treatment. For the person who is aware (a user of alcohol and other drugs), who does not have a disorder, and who knows that he is coming to be hospitalized, it has to be the case that he wants it or accepts it. Force doesn't work out well. That is appropriate for the situation with a patient with a disorder. It is a different situation, in which the person has no awareness of what he has, of the disorder which is happening with him, of the illness which is taking place (N8).

It is worth emphasizing that, at some points, the users of alcohol and other drugs may not present critical judgment regarding their mental health conditions. Some behaviors or manifestations, such as tolerance, abstinence, increase in consumption, desire to reduce use without success, abandonment or reduction in social and family coexistence are some of the criteria which characterize addiction. ${ }^{25}$ In these situations, hospitalization may be an important resource for stabilizing the service user. The hospitalizations are indicated in cases considered serious, when there is a risk to the patient himself, his family or for society, or a risk of social exposure.

The specific characteristics of the mental disorders and the use of alcohol and other drugs show the importance of professional qualification and of the nurses' understanding referent to hospitalizations in each situation, so that - based on whatever it is that characterizes each point - they may elaborate therapeutic care plans. In this way, the psychiatric hospitalizations are indicated for a short period, when the extrahospital resources have been exhausted, hospitalization in places with characteristics of asylums being legally prohibited. Hospitalizations present as their purpose the stabilization of the service user's clinical and psychic situation and the adjustment of a therapy. Corroborating this understanding, the mental health professionals seek to understand the service users' sociocultural and family context, so that the concept of alienation as a contradiction in reasoning will not justify the hospitalizations. ${ }^{22-10}$

Working based on the Psychiatric Reform, and in the comprehensiveness of the care, perceiving the service user's sociocultural and family context, requires communication between the professionals and a care network through which the service user can move without the care being fragmented. According to $\mathrm{N} 1$ and N6, the little communication between the services, and the fragmentation of the mental health network, configure a challenge for the care in this area of work. For them, teamwork meeting the service user's needs could reduce the number of compulsory and involuntary hospitalizations.

The mental health network has many faults, principally of the services. There is no communication between the professionals [...] (N1).

It is a job which involves the entire team, which does not always present communication. The network is not prepared yet [...] The idea would be for the individual to be assisted in all his needs, in all these situations, with quality in his care, with a highly individual approach. However, we know that this is not what happens. We are working so that we will be able to avoid these types of hospitalizations (compulsory and involuntary). Even with the difficulties, when we manage to avoid these, we are satisfied (N6).

The weakness in the mental health care network leads to feelings of frustration in the nurse, as, for example, when the service user attends the extra-hospital service and, however, ends up being hospitalized. The feeling of weakness and impotence is felt, as reported by $\mathrm{N} 4$, when there are no other possibilities apart from the compulsory and involuntary hospitalizations. 
It frustrates us a bit as a service when there is a patient who ends up going for compulsory hospitalization. We have the feeling that we were not able to treat this patient appropriately. It gives you a feeling of failure. (N4)

Mental health care structured on the basis of care networks is fundamental in the process of the inclusion of the service user, as this allows community life and care in the community, contributing to the recovery of the citizenship of the user of the mental health services. For the networks to be implemented efficiently, communication and interaction between the services appear as instruments which are fundamental for the nursing care. ${ }^{26}$ The weakness in the mental health network addressed by the nurses causes feelings of failure, pointing to the need for interaction between the professionals from the health services which make up the Psychosocial Care Network. ${ }^{27}$ As a result, we consider it to be important for there to be spaces for Continuing Education, which promote encounters between professionals for discussions regarding the concepts of care in nursing in mental health, emphasizing the topic of interaction and communication, due to the complexity; and, above all, their importance for the process of caring. ${ }^{26}$ We perceive that - historically - madness has been seen as something that should be normalized, and that hospitalization was the way of reorganizing the person held as mad. With the advent of the Psychiatric Reform, it became possible to perceive changes in relation to the respect and treatment for the service user, as shown in the nurses' accounts when they refer to the care involving the service user and his family. Regarding the challenges, the transformations cannot be only in terms of care; it is necessary that changes should occur in the services' conceptual bases, and changes relating, for example, to the epistemological dimension: the notions of illness, therapy, cure and treatment. ${ }^{23}$

\section{CONCLUSIONS AND IMPLICATIONS FOR PRACTICE}

As the results of this study, we consider that compulsory and involuntary hospitalization must take into account important factors such as family-related and socio-cultural factors, the patient's uniqueness, and his life history. In addition to this, from the nurses' accounts, it is possible to perceive the suffering of family members when they undertake the hospitalization. The nurses emphasize that, generally speaking, hospitalization takes place when there is suffering among the family members and these cannot find other solutions apart from hospitalization. Regarding the understanding of the different modalities of hospitalization, in their accounts, the nurses did not raise elements differentiating these. The accounts did not limit themselves to the specific characteristics of each type of hospitalization, but, rather, to the care for the users of the mental health services. This study's results point to the difficulty in communicating between the services which make up the mental health care network, configuring a challenge for comprehensive care in mental health. Based on their understanding of compulsory and involuntary hospitalization, the nurses can think about discussion spaces which promote reflexion regarding the quality of the care. We think that we can put this possibility into effect through Continuing Education spaces which provide opportunities for the problematization of the issue among the nurses and their work teams. We consider it important to emphasize themes such as the communication between services of the mental health care network, psychiatric hospitalization, and the Psychiatric Reform. The nurses' understanding regarding the hospitalizations is a resource which must be used in specific situations, considering the family-related and socio-cultural context and the uniqueness of each service user. Some situations in mental health are held as being conditions which pose risks (clinical and psychosocial, among others) to the service users, and hospitalization may be used as an alternative for care which is safe and liberating. Our hope is that this study may stimulate other debates contributing to research in the area of nursing and to the mental health services, as well as to reflexion on the importance of hospitalization and the ways in which this takes place in the contemporary mechanisms of mental health. As a limitation of the study, we note the difficulty of undertaking the study in some scenarios, due to the turnover of the health teams.

\section{REFERENCES}

1. Moreira LHO, Loyola CMD. Internação involuntária: as implicações para a clínica da enfermagem psiquiátrica. Rev Esc Enferm USP. [Internet]. 2011; [cited 2016 Oct 03]; 45(3):690-7. Available from: http:// www.scielo.br/pdf/reeusp/v45n3/v45n3a21.pdf doi: 10.1590/S008062342011000300021

2. Xavier MS, Terra MG, Silva CT, Mostardeiro SCTS, Silva AA, Freitas FF. O significado da utilização de psicofármacos para indivíduos com transtorno mental em acompanhamento ambulatorial. Esc Anna Nery. [Internet]. 2014; [cited 2016 Oct 19]; 18(2):323-9. Available from: http:// www.scielo.br/pdf/ean/v18n2/1414-8145-ean-18-02-0323.pdf doi: 10.5935/1414-8145.20140047

3. Lei n. 10.216 de 6 de abril de 2001 (BR). Dispõe sobre obre a proteção e os direitos das pessoas portadoras de transtornos mentais e redireciona o modelo assistencial em saúde mental. Diário Oficial da União, Brasília (DF), 9 abr 2001. D.O.U. 68E. Seção 1:2

4. Backes DS, Backes MS, Erdmann AL, Büscher A. O papel profissional do enfermeiro no Sistema Único de Saúde: da saúde comunitária à estratégia de saúde da família. Ciênc Saúde Coletiva. [Internet]. 2012 [cited 2016 Nov 10]; 17(1):223-30. Available from: http://www.scielo.br/ pdf/csc/v17n1/a24v17n1.pdf doi: 10.1590/S1413-81232012000100024

5. Horton R. Launching a new movement for mental health. Lancet [Internet]. 2007; [cited 2016 Nov 09]; 370(9590):806. Available from: http://www.thelancet.com/pdfs/journals/lancet/PIIS01406736(07)61243-4.pdf doi: 10.1016/S0140-6736(07)61243-4

6. Ramos DKR. Reinternações psiquiátricas no Rio Grande do Norte: implicações e impacto das novas estratégias de atenção à saúde menta [tese]. Natal (RN): Universidade Federal do Rio Grande do Norte;2011. $150 \mathrm{p}$.

7. Cavada CT. Concepções de Reforma Psiquiátrica presentes no discurso de profissionais de um Centro de Atenção Psicossocial [dissertação] Pelotas (RS): Universidade Federal de Pelotas; 2011. 70p.

8. Dias CB, Silva ALA. O perfil e a ação profissional da(o) enfermeira(o) no Centro de Atenção Psicossocial. Rev Esc Enferm USP. [Internet]. 2010 [cited 2016 Nov 10]; 44(2):469-75. Available from: http://www.scielo.br/ pdf/reeusp/v44n2/32.pdf doi: 10.1590/S0080-62342010000200032

9. Bardin L. Análise de Conteúdo. 1ª ed. Lisboa: Edições 70; 2011. 280p. 
10. Amarante P. Reforma Psiquiátrica e Epistemologia. Cad Bras Saúde Mental. [Internet]. 2009; [cited 2016 Nov 10]; 1(1):[aprox. 7 telas]. Available from: http://incubadora.periodicos.ufsc.br/index.php/cbsm/ article/view/998

11. Amarante P, Freitas F, Nabuco E, Pande MNR. Da diversidade da loucura à identidade da cultura: o movimento social cultural no campo da reforma psiquiátrica. Cad Bras Saúde Mental. [Internet]. 2012; [cited 2016 Nov 10]; Jan/Jun;4(8):125-32. Available from: http://incubadora. periodicos.ufsc.br/index.php/cbsm/article/view/2026/2317

12. Amarante P. Saúde Mental e Atenção Psicossocial. $4^{a}$ ed. Rio de Janeiro: Fiocruz; 2013. 123p.

13. Mello RM, Schneider JF. A família e a internação psiquiátrica em hospital geral. Rev Gaúcha Enferm (Online). [Internet]. 2011; [cited 2016 Nov 19]; 32(2):226-33. Available from: http://www.scielo.br/pdf/ rgenf/v32n2/a03v32n2.pdf doi: 10.1590/S1983-14472011000200003

14. Dimenstein M, Sales AL, Galvão E, Severo AK. Estratégia da atenção psicossocial e participação da família no cuidado em saúde mental. Physis. [Internet]. 2010 dez; [cited 2016 Nov 10]; 20(4):1209-26. Available from: http://www.scielo.br/pdf/physis/v20n4/a08v20n4.pdf doi: 10.1590/S0103-73312010000400008

15. Pegoraro RF. Papéis atribuídos à família na produção da loucura: algumas reflexões. Bol Acad Paul Psicol. [Internet]. 2009; [cited 2016 Nov 15]; 29(2):253-73. Available from: http://pepsic.bvsalud.org/pdf/ bapp/v29n2/v29n2a04.pdf

16. Amarante P. Novos sujeitos, novos direitos: o debate sobre a reforma psiquiátrica no Brasil. Cad Saúde Pública. [Internet]. 1995 jul/set; [cited 2016 Oct 15]; 11(3):491-4. Available from: http://www.scielo.br/pdf/csp/ v11n3/v11n3a11.pdf doi: 10.1590/S0102-311X1995000300024

17. Hori AA, Nascimento AF. O Projeto Terapêutico Singular e as práticas de saúde mental nos Núcleos de Apoio à Saúde da Família (NASF) em Guarulhos (SP), Brasil. Ciênc Saúde Coletiva. [Internet]. 2014; [cited 2016 nov 15]; 19(8):3561-71. Available from: http://www.scielo. br/pdf/csc/v19n8/1413-8123-csc-19-08-03561.pdf doi: 10.1590/141381232014198.11412013

18. Soccol KLS, Terra MG, Ribeiro DB, Teixeira JKS, Siqueira DF, Mostardeiro SCTS. O cotidiano das relações familiares com indivíduo dependente químico. Cogitare Enferm. [Internet]. 2014 jan/mar; [cited 2016 Nov 15]; 19(1):116-22. Available from: http://revistas.ufpr.br/ cogitare/article/view/35967/22176 doi: 10.5380/ce.v19i1.35967

19. Eloia SC, Oliveira EN, Eloia SMC, Lomeo RC, Parente JRF. Sobrecarga do cuidador familiar de pessoas com transtorno mental: uma revisão integrativa. Saúde Debate. [Internet]. 2014; [cited 2016
Nov 14]; 38(103):996-1007. Available from: www.scielo.br/pdf/sdeb/ v38n103/0103-1104-sdeb-38-103-0996.pdf doi: 10.5935/01031104.20140085

20. Silva CT, Terra MG, Camponogara S, Kruse MHL, Roso CC, Xavier MS. Educação permanente em saúde a partir de profissionais de uma residência multidisciplinar: estudo de caso. Rev Gaúcha Enferm. [Internet]. 2014 Set; [cited 2016 Nov 12]; 35(3):49-54. Available from: http://www.scielo.br/pdf/rgenf/v35n3/pt_1983-1447rgenf-35-03-00049.pdf doi: 10.1590/1983-1447.2014.03.44512

21. Medeiros GT, Nascimento FAF, Pavon RG, Silveira FA. Educação Permanente em Saúde Mental: relato de experiência. Interface (Botucatu). [Internet]. 2016 Jun; [cited 2016 Nov 12]; 20(57):47584. Available from: http://www.scielo.br/scielo.php?pid=S1414$32832016000200475 \&$ script=sci_abstract\&tlng=pt doi: $10.1590 / 1807-$ 57622015.0232

22. Cardoso L, Galera SAF. O cuidado em saúde mental na atualidade. Rev Esc Enferm USP. [Internet]. 2011; [cited 2016 Nov 03]; 45(3):687-91. Available from: http://www.scielo.br/pdf/reeusp/v45n3/v45n3a20.pdf doi: 10.1590/S0080-62342011000300020

23. Amarante PDC. Reflexões sobre a Luta Antimanicomial: (En)Cena entrevista Paulo Amarante. (En)Cena [Internet]. 2012; [cited 2016 Aug 18]. Available from: http://encenasaudemental.net/comportamento/ entrevista/reflexoes-sobre-a-luta antimanicomial-encena-entrevistapaulo-amarante/

24. Monteiro FH. A internação psiquiátrica compulsória: uma abordagem à luz dos direitos fundamentais [mestrado]. Porto Alegre (RS): Pontifícia Universidade Católica do Rio Grande do Sul; 2015. 252p.

25. American Psychiatric Association. DSM-IV-TR: Manual diagnóstico e estatístico de transtornos mentais. $4^{\mathrm{a}}$ ed. Porto Alegre: Artmed; 1995 975p.

26. Paes MR, Maftum MA. Comunicação entre equipe de enfermagem e pacientes com transtorno mental em um serviço de emergência Ciênc Cuid Saúde. [Internet]. 2013 jan/mar; [cited 2016 Nov 03]; 12(1):55-62. Available from: http://periodicos.uem.br/ojs/index.php/ CiencCuidSaude/article/view/15830 doi: 10.4025/cienccuidsaude. v12i1.15830

27. Portaria n. 3.088 de 23 de dezembro de 2011 (BR). Institui a Rede de Atenção Psicossocial para pessoas com sofrimento ou transtorno mental e com necessidades decorrentes do uso de crack, álcool e outras drogas, no âmbito do Sistema Único de Saúde (SUS). Diário Oficial da União. Brasília (DF), 23 dez. 2011. D.O.U. no 247. Seção 1 230/232.

\footnotetext{
${ }^{a}$ In developing the categories, we will use the term "service user", considered to be a person who has social participation in the mental health scenarios. ${ }^{12}$
} 